\title{
AN EMERGENCY STRATEGY FRAMEWORK FOR MANAGING COVID-19 IN LONG-TERM CARE FACILITIES IN BRAZIL
}

\section{Uma estratégia de emergência estruturada para o gerenciamento da COVID-19 em instituições de longa permanência no Brasil}

\author{
Peter Lloyd-Sherlock ${ }^{\mathbb{D}}$, João Bastos Freire Neto ${ }^{\mathrm{b}} \mathbb{B}$, Meirelayne Duartec ${ }^{\mathbb{D}}$, \\ Monica Frank ${ }^{d}\left(\mathbb{D}\right.$, Karla Giacomine (D), Paulo José Fortes Villas Boas ${ }^{f}(\mathbb{D}$, \\ Fabiana da Cunha Saddis (1), Patrick Alexander Wachholz $[$ (1)
}

\begin{abstract}
This paper presents a novel policy framework to support government responses to COVID-19 in long-term care facilities (LTCFs) in low and middle-income countries. It focuses on issues that are of specific relevance to Brazilian policy-settings, including examples of its local implementation. The CIAT Framework combines and summarizes broad elements for an emergency strategy to address the potential effects of COVID-19. The 4 steps of the Framework entail policies to coordinate, identify, assess, and target support. Those policies can be applied immediately to mitigate the impact of the COVID-19 pandemic in LTCFs. It is, however, essential to situate these responses within a more comprehensive and permanent strategy. Intersectoral collaboration must evolve into a fully institutionalized system.
\end{abstract}

KEYWORDS: aged; coronavirus infections; developing countries; Brazil.

Este artigo apresenta uma nova estrutura de política para dar apoio às respostas do governo à COVID-19 em instituições de longa permanência para idosos (ILPIs) em países de baixa e média renda. Se concentra em questões que são de relevância específica às organizações que decidem sobre as políticas brasileiras, incluindo exemplos de sua implementação local. A Estrutura CIAT combina e resume elementos amplos de uma estratégia de emergência para abordar os potenciais efeitos da COVID-19. As 4 etapas da Estrutura envolvem políticas voltadas para a coordenação, identificação, avaliação e trabalho do apoio focado. Essas políticas podem ser aplicadas imediatamente para atenuar o impacto da pandemia de COVID-19 nas ILPIs. É, no entanto, essencial situar essas respostas dentro de uma estratégia mais abrangente e permanente. A colaboração intersetorial deve evoluir para um sistema totalmente institucionalizado.

PALAVRAS-CHAVE: idoso; infecções por coronavírus; países em desenvolvimento; Brasil.

aSchool of International Development, University of East Anglia - Norwich, United Kingdom.

bMunicipal Health Secretariat of Fortaleza - Fortaleza (CE), Brazil.

Universidade Salvador - Salvador (BA), Brazil.

dState Referral Center for Geriatric Care - Salvador (BA), Brazil.

ePublic Health and Aging Study Center, René Rachou Institute, Oswaldo Cruz Foundation - Belo Horizonte (MG), Brazil.

fDepartment of Internal Medicine, Botucatu Medical School, Universidade Estadual Paulista "Júlio de Mesquita Filho" - Botucatu (SP), Brazil.

sSchool of Social Sciences, Universidade Federal de Goiás - Goiânia (GO), Brazil.

Correspondence data: Peter Lloyd-Sherlock - School of International Development, University of East Anglia - Norwich Research Park - Norfolk NR4 7TJ - Norwich, United Kingdom. E-mail: p.lloyd-sherlock@uea.ac.uk @peterls1605

Received on: 03/21/2021. Accepted on: 04/12/2021

How to cite this article: Lloyd-Sherlock P, Freire Neto JB, Duarte M, Frank M, Giacomin K, Villas Boas PJF, et al. An emergency strategy framework for managing COVID-19 in long-term care facilities in Brazil. Geriatr Gerontol Aging. 2021;15:e0210014. https://doi.org/10.5327/Z2447-212320212100030 https://doi.org/10.5327/22447-212320212100030 


\section{INTRODUCTION}

This paper summarizes key elements of a novel policy framework to support government responses to COVID-19 in long-term care facilities (LTCFs) in low and middle-income countries (LMICs). ${ }^{1}$ The CIAT Framework was developed as an ad hoc emergency document, drawing on available evidence and rapid consultation between academic experts and policy-makers. It is a "live document," which has been updated since its original publication. This paper focuses on elements of the Framework relevant to Brazilian policy-settings, including actual examples of its implementation.

In high-income countries, LTCFs have accounted for a disproportionate share of total COVID-19 mortality, which has prompted the development of specific technical guidance by global agencies, including the World Health Organization. ${ }^{2}$ Official data on COVID-19 in Brazilian LTCFs are very incomplete. Indeed, information on the number of LTCFs and their population is very limited for Brazil. It has been estimated that the country has at least $0.03 \mathrm{LTCF}$ residents per head of population aged 80 or over, which is considerably lower than numbers reported for high-income countries. However, data gaps mean that this is likely to be an underestimate and there is evidence that the sector is growing quickly. ${ }^{3}$

There are several reasons why wealthier countries' strategies may not be equally applicable to most LMICs, including Brazil. Engagement between state agencies and Brazilian LTCFs tends to be relatively limited. Most facilities are small and privately-run, and unlike higher-income countries, few receive systematic financial support as part of an established long-term care system. LTCF funding comes mainly through a combination of older people's retirement benefits and payments from their families. Less frequently, funding comes from local organizations, charities, and municipal governments. ${ }^{4}$ Also, many LTCFs are neither listed nor registered by Brazilian government agencies. It is estimated that, in some regions, there are at least as many "invisible", unregistered facilities as registered ones. ${ }^{5}$ Even for registered facilities, state regulation and quality control are often minimal. Responsibility for enforcing regulations across LTCFs is devolved to local government agencies, but coordination between health and social departments is often very limited. Furthermore, coordination between local agencies and national ones with wider responsibilities for LTCFs is also often weak.

LTCFs in Brazil are highly diverse, ranging from "boarding houses" with untrained staff to luxury nursing homes claiming to have a full range of therapeutic services. Unlike high-income countries, many prefer to admit older people with little, if any, care dependency. ${ }^{6}$ In the absence of regulation, information about service quality is very limited. However, it is evident that residents often share rooms, facilities are often limited, and skilled staff in short supply. ${ }^{7}$

\section{THE CIAT FRAMEWORK}

The CIAT Framework combines and summarizes broad elements for an emergency strategy to address the potential effects of COVID-19. The different steps and components for the Framework are summarized in Table 1.

\section{Step 1: Coordinate}

Any strategy must be led by an interagency and interdisciplinary Task Force, with seamless coordination between health and social agencies. The Task Force must have backing from the highest levels of government. The Task Force must urgently develop a basic set of guidance suited to the local realities of LTCFs.

In Brazil, government responsibility for LTCFs mainly resides with local and national departments of social assistance. Before the pandemic, this already led to difficulties in responding to these facilities' needs for specific forms of support from and interaction with health agencies. Since the onset of COVID-19, this issue has become much more acute, as health agencies are directly involved in surveillance, testing, vaccination, and other key areas of action. In some municipalities, such as Fortaleza and Belo Horizonte, this has prompted unprecedented intersectoral cooperation. In the state of Bahia and Botucatu (São Paulo state), cooperation has extended to the inclusion of local universities and other agencies in new commissions. ${ }^{8}$ This facilitated rapid information sharing and interagency emergency surveys of LTCFs during the early stages of the pandemic. ${ }^{9}$ Interagency cooperation also facilitated LTCF priority access to testing and vaccines, as they became available.

The Task Force must urgently develop basic and feasible guidance and protocols suited to the local realities of LTCFs. The Task Force should quickly identify the most straightforward and most affordable measures that can realistically be implemented in all LTCFs, including the most precarious and poorly resourced ones.

\section{Step 2: Identify}

The Task Force must develop specific strategies to locate and develop constructive engagement with all LTCFs in their area: registered, unregistered, and de facto ones. The Task Force should be empowered to offer all facilities some form of "amnesty" for past and ongoing infractions of official LTCF standards, on condition that they cooperate with the CIAT Strategy. 
Table 1. The CIAT Framework.

\begin{tabular}{|c|c|c|c|c|}
\hline Coordinate & Type of LTCF & Identify & Assess and risk-rate & Targeted support \\
\hline \multirow{4}{*}{$\begin{array}{l}\text { Create new } \\
\text { cross-agency } \\
\text { task force } \\
\text { with high-level } \\
\text { support }\end{array}$} & $\begin{array}{l}\text { Registered with } \\
\text { good information }\end{array}$ & Verify existing lists & $\begin{array}{l}\text { Short survey tool } \\
\text { (enhance ones } \\
\text { already being applied) }\end{array}$ & $\begin{array}{l}\text { Do not enforce pre-COVID-19 } \\
\text { protocols, just ensure they } \\
\text { are doing the key things to } \\
\text { manage COVID-19 risk } \\
\text { Relocate less } \\
\text { care-dependent residents? }\end{array}$ \\
\hline & $\begin{array}{l}\text { Registered in } \\
\text { theory, but } \\
\text { little reliable } \\
\text { information }\end{array}$ & $\begin{array}{l}\text { Use registration lists to conduct } \\
\text { brief telephone interview to check } \\
\text { LTCF still operates and get some } \\
\text { basic information (eg, updated } \\
\text { contact details of director). } \\
\text { Explain context of assessment } \\
\text { survey and reassure that no } \\
\text { prosecutions for infractions of } \\
\text { protocols will occur. }\end{array}$ & Ditto & Ditto \\
\hline & Unregistered & $\begin{array}{l}\text { Multiple means: local } \\
\text { stakeholders, public engagement, } \\
\text { reassure that will only prosecute } \\
\text { in most extreme forms of abuse }\end{array}$ & $\begin{array}{l}\text { Same survey tool, but } \\
\text { perhaps administered } \\
\text { by a less official } \\
\text { agency (seen as less } \\
\text { of a threat) }\end{array}$ & Ditto \\
\hline & De facto & Ditto & Ditto & Ditto \\
\hline
\end{tabular}

The Task Force will need to locate and engage with all facilities rapidly. Unregistered homes may be located by local NGOs, civil society organizations, key informants, and appeals to the general public. Bahia state's Intersectoral Commission for Monitoring developed an effective strategy to identify all LTCFs. It reviewed, verified, and combined existing lists of LTCFs held separately by different local agencies. Additionally, information about LTCFs was obtained from health and social assistance managers. All LTCFs were contacted either by phone or email. When this was not possible, the Commission requested local agencies to verify their records. Between April and September 2020, they identified 200 facilities, including informal shared living arrangements that did not self-identify as LTCFs. ${ }^{8}$ In 2021 , residents and staff in all these facilities have been provided COVID-19 vaccinations. In other parts of Brazil, where registers of LTCFs are often incomplete, their full inclusion in vaccination will be much harder to achieve.

LTCF engagement must consider the feasibility and legal status of different sets of guidance, protocols, advice, and standards, including those that predate the pandemic and those produced since. If these entail legally mandated requirements, some LTCFs may perceive them as a threat and be reluctant to engage. It may be appropriate to offer LTCFs some form of "amnesty" for past and ongoing infractions of nonessential official standards, so long as they agree to cooperate. There are ethical parallels with collaborations between public health entities and illegal brothels to improve control of HIV. ${ }^{10}$ Any amnesties should be framed as pragmatic, temporary emergency measures and should not extend to more serious infractions such as abuse of residents. This approach has been taken in the Province of Buenos Aires in Argentina, with emergency legislation permitting LTCFs not previously registered or not compliant with standards to continue operating without prosecution until a phase of "regularization" had been completed at an unspecified future date. ${ }^{11}$ Therefore, it will be important to involve members of the Brazilian judicial system in this phase of the strategy.

\section{Step 3: Assess}

The Task Force should conduct an emergency survey of local LTCF preparations and vulnerability to COVID-19. This survey information can be used to identify LTCFs at greatest risk based on simple criteria. The Task Force should continue collecting data and maintaining a dialogue with LTCFs to monitor the unfolding situation and respond to new concerns. 
This emergency survey should entail a short, focused, and simple online or email questionnaire collecting the most immediately relevant information. In Fortaleza, it was found that all LTCFs were facing serious challenges to prepare for the pandemic. However, a small number were especially vulnerable, lacking any capacity to screen for potential symptoms and struggling to access daily food and medicines. These high-risk LTCFs were targeted for priority support, and the city's health and social assistance departments continue to work closely with them. ${ }^{9}$ In Bahia, all facilities are remotely assessed using a standard questionnaire applied by phone. After the initial assessment, they are routinely monitored every 72 hours, or on a daily basis when a suspected and/or confirmed case of COVID-19 is present.

\section{Step 4: Targeted support}

LTCFs identified as high-risk should be given priority status for targeted support, emphasizing cooperation rather than punitive measures. It may be necessary for high-risk LTCFs to be put under the Task Force's direct control if their management is unable to cope.

The city government of Belo Horizonte conducted an emergency survey of 179 facilities. ${ }^{2}$ It applied several criteria, including the number of residents per room, access to protective equipment, and capacity to isolate cases, to identify LTCFs most in need of support. These LTCFs received priority support from multidisciplinary teams, including monitoring residents for potential COVID-19 symptoms and developing realistic protocols.

Targeted support should reflect local conditions, as well as emerging knowledge and technologies. This now includes COVID-19 vaccination, but that should not neglect other measures, such as testing and prevention. Task Forces should provide training, support, and necessary materials to LTCF staff. The Brazilian state of Bahia has developed emergency online education and training to staff, ${ }^{8}$ linked to a wider National Movement for Supporting LTCFs. ${ }^{12}$

Checks should be made of LTCF staff who work across multiple facilities, and this practice should be discouraged. This has been an important mechanism of viral entry into LTCFs in some countries. ${ }^{13}$ In Brazil, there are reported cases of LTCF staff working in both health facilities and LTCFs, including COVID-19 Reference Centers. ${ }^{7}$ This is another reason for strong coordination between local health and social assistance agencies. Interventions to support LTCF staff should be mindful of their concerns and, in many cases, their limited prior training, low status, and insecure work contracts. There is a need to guarantee salary during quarantine periods for staff who are tested positive. In Brazil, new legislation passed in April 2020 stipulates all employees be paid in full for the first 15 days of sick leave or social isolation due to COVID-19, and employers can deduct this from social security payments. ${ }^{14}$ However, most LTCF workers in Brazil are employed on an informal basis, so this does not apply to their situation.

\section{SUSTAINING THE CIAT FRAMEWORK AND BUILDING A LEGACY OF IMPROVED PROVISION}

This paper focuses on effective policies that can be immediately applied to combat the COVID-19 pandemic in LTCFs. It is, however, important to situate these responses within a wider and longer-term strategy. The engagement and information acquired through emergency responses are valuable resources, which should be maintained, developed, and kept up to date. Intersectoral collaboration must evolve into a new, fully institutionalized system.

\section{ACKNOWLEDGMENTS}

Our recognition and acknowledgments to all researchers and collaborators from the Global Platform (corona-older. com) and the 'Frente Nacional de Fortalecimento às ILPIs' (frentenacionalilpi.com.br).

\section{CONFLICT OF INTERESTS}

The authors declare no conflicts of interest.

\section{FUNDING}

This paper's research was partly funded by the UKRI GCRF/Newton Fund Agile Response Fund, project reference EP/V043110/1.

\section{AUTHORS' CONTRIBUTION}

PL-S: validation, visualization, writing - review \& editing.JBFN: conceptualization, funding acquisition, writing original draft. MD: conceptualization, funding acquisition, writing - original draft. MF: conceptualization, funding acquisition, writing - original draft. KG: conceptualization, funding acquisition, writing - original draft. PAW: conceptualization, funding acquisition, writing - original draft. PJFVB: conceptualization, funding acquisition, writing - original draft. FCS: writing - original draft. 


\section{REFERENCES}

1. Lloyd-Sherlock P, Giacomin K, Duarte M, Frank M, Redondo N, Sempe $L$, et al. An emergency strategy for managing COVID-19 in long-term care facilities in low and middle-income countries: the CIAT Framework (Version 2). Available from: https://corona-older. com/2020/11/24/an-emergency-strategy-for-managing-covid-19in-long-term-care-facilities-in-low-and-middle-income-countriesthe-ciat-framework-version-2/. Accessed on Mar 12, 2021.

2. World Health Organization. Infection prevention and control guidance for long-term care facilities in the context of COVID-19. World Health Organization; 2021. Available from: https:/apps.who.int/iris/bitstream/ handle/10665/338481/WHO-2019-nCoV-IPC_long_term_care-2021.1-eng. pdf? sequence=1\&isAllowed=y. Accessed on Mar 12, 2021.

3. Watanabe HAW, Domingues MARC, Duarte YAO. COVID-19 and homes for the aged: care or an announced death? Geriatr Gerontol Aging. 2020;14(2):143-5. https://doi.org/10.5327/Z24472123202020142 LTTR

4. Jacinto AF, Achterberg W, Wachholz PA, Dening T, Harrison Dening K, Devi R, et al. Using international collaborations to shape research and innovation into care homes in Brazil: a white paper. J Nursing Home Res. 2020;6:109-13. http://dx.doi.org/10.14283/jnhrs.2020.28

5. Wachholz PA, Jacinto AF, Melo RC, Dinamarca-Montecinos JL, Boas PJFV. COVID-19: challenges in long-term care facilities for older adults in Hispanic American countries. Geriatr Gerontol Aging. 2020;14(4):25966. https://doi.org/10.5327/Z2447-212320202000085

6. Lacerda T, Horta N, Souza M, Oliveira RT, Marcelino KGS, Ferreira QN. Caracterização das Instituições de longa permanência para idosos da região metropolitana de Belo Horizonte. Rev Bras Geriatr Gerontol [Internet] 2017 [Accessed on 2021 Mar 12];20(6):74353. Available in: https://www.scielo.br/pdf/rbgg/v20n6/pt_18099823-rbgg-20-06-00743.pdf. https://doi.org/10.1590/198122562017020.170014

7. Wachholz PA, Moreira VG, Oliveira D, Watanabe HAW, Boas PJFV. Estimates of infection and mortality from COVID-19 in care homes for older people in Brazil. Geriatr Gerontol Aging. 2020;14(4):290-3. https://doi.org/10.5327/Z2447-212320202000127
8. Duarte M, Frank M, Soub J, Patáro H, Costa J, Oliveira D. Developing and implementing a strategy for COVID-19 and long-term care facilities for older people in the Brazilian state of Bahia. Available from: https://corona-older.com/2020/11/05/developing-andimplementing-a-strategy-for-covid-19-and-long-term-care-facilitiesfor-older-people-in-the-brazilian-state-of-bahia/. Accessed on Mar 12, 2021.

9. Bastos J, Lloyd-Sherlock P. Letter from Brazil: COVID-19 and older people in Fortaleza, Brazil's worst-hit city. Available from https:// corona-older.com/2020/05/23/letter-from-brazil-covid-19-andolder-people-in-fortaleza-brazils-worst-hit-city/. Accessed on Mar 12, 2021.

10. Ghose T, Swendeman D, George S. The role of brothels in reducing HIV risk in Sonagachi, India. Qual Health Res. 2011;21(5):587-600. https://doi.org/10.1177/1049732310395328

11. Sistema Argentino de Información Juridica. Declaran el estado de emergencia sanitaria de los establecimientos geriátricos, de gestión pública y privada, en toda la provincia de Buenos Aires. 2020. Available from: http://www.saij.gob.ar/\%20LPB0015171?utm_source=newslettersemanal\&utm_medium=email\&utm_term=semanal\&utm_campaign=leyprovincial. Accessed on Mar 12, 2021.

12. Unidos pela proteção da pessoa idosa. National Movement for Supporting LTCFs. Available from: https://www.frentenacionalilpi. com.br/. Accessed on Mar 12, 2021.

13. Fortiér J. They Work In Several Nursing Homes To Eke Out A Living, And That May Spread The Virus. Available from: https://www.npr org/sections/health-shots/2020/10/26/927841874/they-work-inseveral-nursing-homes-to-eke-out-a-living-and-that-spreads-theviru?t=1607706531099. Accessed on Mar 12, 2021.

14. Government of Brazil. Orientação sobre a dedução nas contribuições previdenciárias do custo salarial dos primeiros 15 dias de afastamento de empregado com Covid-19. 2020. Available from: https://www.gov. $\mathrm{br} / \mathrm{esocial} / \mathrm{pt}-\mathrm{br} / \mathrm{documentacao-tecnica/manuais/nota-orientativa-}$ 2020-21-deducao-nas-cps-dos-15-de-afastamento-por-covid-19-v2. pdf. Accessed on Mar 12, 2021. 